\title{
Histone H3.3
}

National Cancer Institute

\section{Source}

National Cancer Institute. Histone H3.3. NCI Thesaurus. Code C101445.

Histone H3.3 (136 aa, $\sim 15 \mathrm{kDa}$ ) is encoded by both the human H3-3A and H3-3B genes.

This protein plays a role in chromosomal structure. 